\title{
Validation of Indonesian Words Memory Test
}

\author{
Erydani Anggawijayanto \\ Faculty of Psychology, Gadjah Mada University, Yogyakarta \\ erydani.anggawijayanto@gmail.com \\ Thomas Dicky Hastjarjo \\ Faculty of Psychology, Gadjah Mada University, Yogyakarta \\ dickyh@ugm.ac.id
}

\begin{abstract}
Working memory not only temporarily stores information but also actively processes information to perform complex cognitive tasks. Working memory components have different functions such as storing specific verbal and auditive information, visual and spatial information storage areas and there are components that control both systems. One way to retrieve stored information is by recall technique. This study used twelve concrete nouns tested in the form of 12 sequence formats. The twelve formats were tested on I20 people so that each format was tested on 10 participants. Each word produces scores based on achievement tests in each sequence. The participants of this study were adult individuals aged 19-30 years, consisting of 24 male and 96 female participants. Difficulty level $(P)$ of each word, i.e the number of correct answers is divided by the number of total answerers, calculated in each order format. For each sequence a word is chosen with the difficulty level of $p=0.03$ 0.05 . The participants of this study were adult individuals aged 19-30 years, consisting of 24 male and 96 female participants. This study developed a memory test of Indonesian nouns that had psychometric parameters.
\end{abstract}

Keywords: Concreteness level, memory test, level of difficulty, words order.

Received 7 November 2020/Accepted 5 March 202I CAuthor all rights reserved

\section{Introduction}

Memory is a process that carries out three functions, namely transformation of sensory data into a form of mental representation, storing the encoded information as well as retrieving and using the information from storage (Sternberg, R. J., \& Sternberg, 2012). Working memory can be interpreted as a temporary storage system that processes information before it is stored in long-term memory (Baddeley, 20II). Auditory and phonological information will be processed in the phonological loop while visuospatial sketchpad will process visual and spatial information (Baddeley, 2003; 20I I). 
The retrieval process can be measured in two ways, namely by recall tests and recognition tests (Solso, Maclin \& Maclin, 2008; Sternberg \& Sternberg, 2012). Recall itself is defined as the ability to explore and produce information that has been previously owned (Sternberg, R. J., \& Sternberg, 2012: Solso, et al, 2008: Wade \&Tavris, 2007). Meanwhile, recognition is the ability to recognize information that has been obtained previously, one example of recognition tests is multiple choice questions (Wade \&Tavris, 2007) and recall tests are exemplified in the form of essay or essay questions (Solso, et al, 2008). The ability of humans to store information in the short term memory is seven pieces of information or chunk (Baddeley, Hitch, \& Allen, 2009; Bhinnety, 2008; Miller, 1956; Solso et al, 2008;). In general memory tests on working memory research use six pairs or twelve unrelated nouns (Halsband, 2006) or fifteen words in sentence form (Baddeley et al, 2009).

Memory tests use various stimuli, one of which uses words as stimuli. Following the tradition of Paivio, Hastjarjo made a memory test by using nouns with the following three characteristics, namely the level of imagery or difficulty-ease to imagine (Hastjarjo, 2004; Paivio, 2013; Paivio, Yuille \& Madigan, 1968) level of concreteness-abstractness (Hastjarjo, 2004; Paivio, 20I3; Paivio et al, 1968), level of meaningfulness (Hastjarjo, 2004; Paivio et al, 1968) and sometimes pronouncibility (Spreen \& Schulz, 1966). In addition to these parameters, if a memory test is analogous to an achievement test then the memory test should also have a difficulty level parameter, symbolized by the letter $\mathrm{P}$ (Azwar, 20I4).

The list of words or word pool compiled by Hastjarjo (2004) has a level of concreteness, level of imagery, and level of meaningfulness that has been tested from three ethnic groups in Indonesia, Java, Sunda and Bali. The word list consists of 300 nouns which 244 of them have the same level of difficulty according to the judgment of the three ethnic groups. This study selected 12 nouns (see Table I) from 244 nouns with the same level of difficulty and each word must consist of two syllables with 5-7 letters.

Based on the previous studies and the purpose of memory test development, this research became necessary. In cognitive study, memory research is an attractive study (Sternberg \& Sternberg, 2012), so that exist of numerous memory test is important. Indonesia has limited 
memory test based on words. Memory test based on word pair is available in some memory test tools, but memory test based on word sequential is limited.

Difficulty level index items from each word from the word list would be calculated. Item difficulty index $(P)$ is the ratio between the number of correct answerers of an item and the number of answerers of the item. The difficulty index is an empirical possibility for a pass item for a particular group of students (Azwar, 20l4). The value of $p$ equals 0 will show that the item is very difficult while the value of $p$ equals $I$ indicates the item is too easy because it is successfully answered by all the answerers. The item difficulty index can be formulated as follows:

$$
\mathrm{p}=\frac{\mathrm{n} 1}{\mathrm{~N}}
$$

$P=$ item difficulty index.

$\mathrm{nI}=$ Number of participants who answered the item correctly.

$\mathrm{N}=$ Number of participants

The ideal $p$ value, although not absolute, is in the range of scores $p=0.50$. Sometimes $p$ values less than 0.50 are used to get more difficult items with specific goals (Azwar, 20I4). Therefore, the desired $p$ value in this study is $0.30 \leq p \leq 0.50$, so items that have medium difficulty levels will be obtained and correspond to each word sequence. 
Table I

List of I 2 nouns (adapted from Hastjarjo (2004)

\begin{tabular}{ccccccc}
\hline No & Words & $\begin{array}{c}\text { Nof } \\
\text { letter }\end{array}$ & $\begin{array}{c}\text { N of } \\
\text { syllables }\end{array}$ & Javanese & Sundanese & Balinese \\
\hline I & Lulur & 5 & 2 & 5.92 & 6.04 & 6.42 \\
2 & Pulsa & 5 & 2 & 3.64 & 3.25 & 3.57 \\
3 & Pistol & 6 & 2 & 6.52 & 6.87 & 6.45 \\
4 & Filter & 6 & 2 & 5.01 & 5.13 & 5.59 \\
5 & Cermin & 6 & 2 & 6.72 & 6.92 & 6.61 \\
6 & Karcis & 6 & 2 & 6.75 & 6.64 & 6.71 \\
7 & Wayang & 6 & 2 & 6.57 & 6.57 & 6.57 \\
8 & Pemuda & 6 & 3 & 5.64 & 6.21 & 6.00 \\
9 & Komedi & 6 & 3 & 3.27 & 3.60 & 3.44 \\
I0 & Rayuan & 6 & 3 & 2.96 & 5.06 & 3.19 \\
II & Listrik & 7 & 2 & 3.46 & 4.14 & 3.98 \\
I2 & Sarapan & 7 & 3 & 5.01 & 4.68 & 5.64 \\
\hline
\end{tabular}

The purpose of this study is to find out the difficulty level of each noun in the sequence of 12 nouns in a memory test. So that this research is expected to produce proper, valid noun sequences to be used in noun memory tests. It was complete and enrich previous study about concrete words level (Hastjarjo, 2004), noun arrangement as memory test (Prakosa, Purnamaningsih, Dewajani, \& Hastjarjo, 2008). Furthermore, memory test in sentence format used (Baddeley, Hitch \& Allen, 2009) form working memory, and paragraph was applicated as memory test in Tes Memori Indonesia (LPSP3UI).

\section{Method}

\section{Participants}

The participants were 120 students consisting of 96 women and 24 men and had an age range from 19 to 30 years. Participants were undergraduate and graduate students in Yogyakarta. Informed consent have been given before procedures, participant should in good health condition, physically and mentally in the test time. After the test, the participant received snack, healthy food and mineral water as compensation for their time and effort. 


\section{Procedure}

Participants were divided into twelve groups and each group gets 12 nouns in different order. So there are 12 word order formats that produce difficulty scores for each word in each sequence 120 subjects were divided into 12 groups according to the order of arrival, each group consisted of 10 people. For each group, ten people sat in parallel facing a slide projector screen within two meters. Twelve nouns were displayed on the projector slide screen, each word displayed for 2 seconds in sequence. After the twelve nouns were displayed, the screen was blank for 10 seconds and then the instruction to recall the 12 words was displayed. All participants were asked to write down their answer on a paper. The same procedure was carried out for the eleven groups with different sequences of the twelve nouns for each group.

\section{Questionnaires}

According to the procedure, the experimenter provides 12 order formats for twelve groups

Tabel 2

Order formats

\begin{tabular}{lllllllllllll} 
I $^{\text {st }}$ & 2nd & 3rd & 4th & 5th & 6th & 7th & 8th & 9th & I0th & IIth & I2th \\
\hline Lulur & Pulsa & Pistol & Filter & Cermin & Karcis & Wayang & Pemuda & Komedi & Rayuan & Listrik & Sarapan \\
Pulsa & Pistol & Filter & Cermin & Karcis & Wayang & Pemuda & Komedi & Rayuan & Listrik & Sarapan & Lulur \\
Pistol & Filter & Cermin & Karcis & Wayang & Pemuda & Komedi & Rayuan & Listrik & Sarapan & Lulur & Pulsa \\
Filter & Cermin & Karcis & Wayang & Pemuda & Komedi & Rayuan & Listrik & Sarapan & Lulur & Pulsa & Pistol \\
Cermin & Karcis & Wayang & Pemuda & Komedi & Rayuan & Listrik & Sarapan & Lulur & Pulsa & Pistol & Filter \\
Karcis & Wayang & Pemuda & Komedi & Rayuan & Listrik & Sarapan & Lulur & Pulsa & Pistol & Filter & Cermin \\
Wayang & Pemuda & Komedi & Rayuan & Listrik & Sarapan & Lulur & Pulsa & Pistol & Filter & Cermin & Karcis \\
Pemuda & Komedi & Rayuan & Listrik & Sarapan & Lulur & Pulsa & Pistol & Filter & Cermin & Karcis & Wayang \\
Komedi & Rayuan & Listrik & Sarapan & Lulur & Pulsa & Pistol & Filter & Cermin & Karcis & Wayang & Pemuda \\
Rayuan & Listrik & Sarapan & Lulur & Pulsa & Pistol & Filter & Cermin & Karcis & Wayang & Pemuda & Komedi \\
Listrik & Sarapan & Lulur & Pulsa & Pistol & Filter & Cermin & Karcis & Wayang & Pemuda & Komedi & Rayuan \\
Sarapan & Lulur & Pulsa & Pistol & Filter & Cermin & Karcis & Wayang & Pemuda & Komedi & Rayuan & Listrik
\end{tabular}




\section{Data Analysis}

To generate matched sequence with proper and valid noun, the data was analyzed manually with Microsoft excel. Every word counted with item difficulty index formula which formulated as $p=n I / N$.

\section{Result}

So overall there were twelve nouns and 12 sequence formats and each of the twelve nouns had a $\mathrm{p}$ value wherever the noun was in the certain sequence format. Descriptive statistics produced the average $p$ value of each noun in a certain order in all 12 sequence format (see Table 2).

Table 3

Item difficulty index ( $p$ value) in each sequence in all sequence format

\begin{tabular}{|c|c|c|c|c|c|c|c|c|c|c|c|c|}
\hline \multirow[t]{2}{*}{ Noun } & \multicolumn{12}{|c|}{ Sequence format } \\
\hline & I & 2 & 3 & 4 & 5 & 6 & 7 & 8 & 9 & 10 & II & 12 \\
\hline Lulur & 0.5 & $\mathrm{I}$ & $\mathrm{I}$ & 0.3 & 0.5 & 0.5 & 0.5 & 0.8 & 0.7 & 0.7 & 0.7 & 0.9 \\
\hline Pulsa & I & 0.2 & 0.4 & 0.6 & 0.4 & 0.7 & 0.7 & 0.7 & 0.5 & 0.4 & 0.6 & 0.6 \\
\hline Pistol & 0.9 & 0.9 & 0.5 & I & I & 0.9 & 0.6 & 0.8 & 0.4 & 0.7 & 0.8 & 0.9 \\
\hline Filter & 0.8 & 0.7 & 0.7 & 0.2 & 0.4 & 0.6 & 0.3 & 0.4 & 0.5 & 0.1 & 0.4 & 0.3 \\
\hline Cermin & I & 0.7 & 0.9 & 0.7 & 0.3 & 0.6 & 0.7 & 0.8 & 0.2 & 0.4 & 0.6 & 0.8 \\
\hline Karcis & 0.9 & 0.7 & 0.5 & 0.9 & 0.4 & 0.1 & 0.2 & 0.3 & 0.5 & 0.4 & 0.4 & 0 \\
\hline Wayang & I & 0.9 & I & I & 0.8 & 0.7 & 0.3 & 0.6 & 0.9 & 0.7 & 0.7 & 0.8 \\
\hline Pemuda & I & 0.5 & 0.6 & 0.6 & 0.9 & 0.7 & 0.6 & 0.8 & 0.8 & 0.5 & 0.3 & 0.5 \\
\hline Komedi & 0.7 & 0.7 & 0.8 & 0.5 & 0.3 & 0.4 & 0.2 & 0.6 & 0.5 & 0.8 & 0.6 & 0.3 \\
\hline Rayuan & 0.9 & 0.8 & 0.8 & 0.7 & 0.3 & 0.4 & 0.6 & 0.2 & 0.4 & 0.7 & 0.8 & 0.2 \\
\hline Listrik & I & 0.8 & 0.7 & 0.8 & 0.8 & 0.5 & 0.7 & 0.9 & 0.6 & 0.6 & 0.3 & 0.4 \\
\hline Sarapan & 0.8 & 0.8 & 0.5 & 0.4 & 0.4 & 0.2 & 0.2 & 0.2 & 0.6 & 0.4 & 0.6 & 0.3 \\
\hline
\end{tabular}

The next step was to make the final sequence of all the 12 nouns based on $p$ values that meet the criteria of $p$ equal to $0.30 \leq p \leq 0.50$. To facilitate in making a memory test with the proper noun sequence, then the $p$ value that does not meet the requirements of 0.30 $\leq p \leq 0.50$ were omitted from table 2 (Table 3 ). 
Tabel 4

Words that have a value of $0.30 \leq p \leq 0.50$ in each sequence

\begin{tabular}{|c|c|c|c|c|c|c|c|c|c|c|c|c|}
\hline \multirow[t]{2}{*}{ Noun } & \multicolumn{12}{|c|}{ Order number } \\
\hline & 1 & 2 & 3 & 4 & 5 & 6 & 7 & 8 & 9 & 10 & II & 12 \\
\hline Lulur & 0.5 & & & 0.3 & 0.5 & 0.5 & 0.5 & & & & & \\
\hline Pulsa & & & 0.4 & & 0.4 & & & & 0.5 & 0.4 & & \\
\hline Pistol & & & 0.5 & & & & & & 0.4 & & & \\
\hline Filter & & & & & 0.4 & & 0.3 & 0.4 & 0.5 & & 0.4 & 0.3 \\
\hline Cermin & & & & & 0.3 & & & & & 0.4 & & \\
\hline Karcis & & & 0.5 & & 0.4 & & & 0.3 & 0.5 & 0.4 & 0.4 & \\
\hline Wayang & & & & & & & 0.3 & & & & & \\
\hline Pemuda & & 0.5 & & & & & & & & 0.5 & 0.3 & 0.5 \\
\hline Komedi & & & & 0.5 & 0.3 & 0.4 & & & 0.5 & & & 0.3 \\
\hline Rayuan & & & & & 0.3 & 0.4 & & & 0.4 & & & \\
\hline Listrik & & & & & & 0.5 & & & & & 0.3 & 0.4 \\
\hline Sarapan & & & 0.5 & 0.4 & 0.4 & & & & & 0.4 & & 0.3 \\
\hline
\end{tabular}

From table 3 it can be seen that the word which has $\mathrm{p}$ corresponding to the first order was the word Lulur and there was no other word that has the desired $p$ score $(0.30 \leq p \leq 0.50)$. For the second order, the only word that meet the criteria $p$ value was the word Pemuda with $p=0.5$. The third sequence has four nouns with corresponding $\mathrm{p}$ values, namely Pulsa $(p=0.4)$, Pistols $(p=0.50)$, Karcis $(p=0.5)$, and Sarapan $(p=0.5)$. In the fourth order three nouns Lulur $(p=0.30)$, Komedi $(p=0.50)$, and Sarapan $(p=0.40)$ meet the criteria. The fifth sequence has eight words with the corresponding $\mathrm{P}$ score, namely the word Lulur, Pulsa, Filter, Cerminl, Karcis, Komedi, Rayuan, and Sarapan. In the sixth order, words that have a corresponding P score are Lulur, Filter, Cermin, Komedi, Rayuan, and Listrik. The p scores that match the criteria for the order of seven are in words, Lulur $(p=0.30)$, Filter $(p=0.30)$, and Wayang $(p=0.30)$. For the eighth order, the matched $p$ score is in the Filter $(p=0.40)$, and tiket $(p=0.30)$. Pulsa $(p=0.50)$, Pistol $(p=0.40)$, Filter $(p=0.50)$, Karcis $(p=0.50)$, Komedi $(p$ $=0.50)$ and Rayuan $(p=0.40)$ are nouns with a value of $p$ that meets the criteria in the order of nine. In the tenth order, words that meet the criteria $p$ score are Pulsa $(p=0.40)$, Cermin and Karcis $(p=0.40)$, Pemuda $(p=0.50)$ and Sarapan $(p=0.40)$. In the order of eleventh, words that meet the criteria $p$ score are Filter $(p=0.40)$, Karcis $(p=0.40)$, Pemuda and Listrik $(p=0.30)$. Finally, in the twelfth order, words that meet the criteria $p$ score are Filter $(p=0.30)$, Pemuda $(p=0.5)$, Komedi $(0.30)$, Listrik $(p=0.40)$ and Sarapan $(p=0.30)$. 


\section{Discussion}

There were four criteria used to compile the final memory test, namely a) a word that has a value of $p=0.50$ will take precedence over other words which have a lower $p$ value, b) a word that has a value of $p=0.40$ will takes precedence over a word with a value of $p=$ 0.30. c) If in a sequence there are several words with the same $p$ value, then the word with the least number of letters will take precedence, and d) words that are located in several sequences and have a variable $p$ value, the word will be placed in a sequence that has a greater $\mathrm{P}$ value. These criteria will experience adjustments under special conditions. Examples of special conditions such as in the word Wayang which only have a value of $p$ according to the criteria in the order of seven, so that the word Wayang will be selected instead of the word Filter which has an identical number of letters and $p$ values.

In the first order, the word that has a $\mathrm{p}$ value is only the word Lulur, so the word Lulur ranks first. The same is true for the second place, only the word Pemuda which has a $P$ value according to the criteria, so the word Pemuda occupies second place. In the third place, there are three words that have a value of $p=0.50$. namely the word Pistol, Tiket, and Sarapan. Based on the previous criteria, the word Pistol is placed as a noun in third place because it has the smallest number of letters. For the fourth position, there are two words that fulfill the requirements, namely the word Komedi and Sarapan, based on the first criteria, the word Komedi will occupy this place. In the fifth position there are eight words that are suitable, but two words have been used in the previous sequence, namely the word Lulur, and Komedi. Pulsa, Filter, Karcis and Sarapan have the same p value, which is 0.40 . Based on the third criterion, the word Pulsa will be placed in fifth position.

The sixth position has two words, Listrik and Rayuan, based on the first criterion, so the word Listrik with $\mathrm{p}=0.50$ is placed in this place. In the seventh position special conditions apply. The words that fit in this place are the word Wayang and Filter, but because the word Wayang has the appropriate $\mathrm{P}$ score in this study only in the order of seven, the word Wayang is chosen for this sequence rather than the word Filter. The word Filter itself is placed in the eighth position because it has a $\mathrm{p}$ score greater than the Karcis with $\mathrm{p}=0.30$. 
The ninth position has six words with the appropriate p score, namely Pulsa, Filter, Karcis, Komedi, Pistol and Rayuan. Because the word Pulsa, Filter, Komedi and Pistol have been used, then the place can only be occupied with either word, Karcis and rayuan. Special conditions also occur in this position, because the word Rayuan does not have a $\mathrm{p}$ value that meet the criteria in the subsequent places, in the position of $10-12$, Then the word Rayuan $(p=0.40)$ to be the selected word rather than the Karcis word $(p=0.50)$.

In the tenth place, there are five words that have $\mathrm{p}$ value that match the criteria, namely the Words Pemuda, Pulsa, Cermin, Karcis and Sarapan. Because the word Pemuda and Pulsa have been used, then there are three words left, namely Cermin, Karcis and Sarapan that have the same $p$ value $(p=0.40)$. The three words cause a special condition to occur between the word Cermin and Karcis which is identical in the number of letters and the value of p, but the word Cermin does not have a corresponding $\mathrm{P}$ value in the order of eleven and twelve. This condition causes the word Cermin to be the word chosen to occupy position ten. For the eleven position there are four words with $\mathrm{p}$ values that match the criteria, but because the words Filter, Pemuda, and Listrik have been used, only the karcis word can be used in this position. This automatically causes the word Sarapan to be the only word left to occupy the twelfth position.

\section{Conclusion}

A memory test of words consisting of 12 nouns has been made based on several systematic steps. This memory test was developed in proper sequence and the order arranged in appropriate difficulty index formula. The order of nouns on the memory test is Lulur $(\mathrm{p}=$ 0.50), Pemuda $(p=0.50)$, Pistol $(p=0.50)$, Komedi $(p=0.50)$, Pulsa $(p=0.50)$, Listrik $(p=$ 0.50), Wayang $(p=0.30)$, Filter $(p=0.40)$, Rayuan (0.40), Cermin $(p=0.40)$, Karcis $(p=0.40)$, and Sarapan $(p=0.30)$. This words order is reliable and valid as memory test than other sequential words. 


\section{Reference}

Azwar, S. (20I4). Tes prestasi. Yogyakarta. Pustaka Pelajar.

Baddeley, A. (2003). Working memory: Looking back and looking forward. Nature Reviews Neuroscience, 4(I0), 829. Doi: https://doi.org/I0.1038/nrn I 201.

Baddeley, A. D. (2006). Working memory: An overview. In S. J. Pickering (Ed.), Working Memory and Education (PP. 3-3I).Burlington, MA: Elsevier. Doi : doi.org//0.1016/B978-012554465-8/50003-X.

Baddeley, A. (2007). Working memory, thought, and action (Vol. 45). Doi : I0.1093/acprof:oso/9780I 98528012.001 .0001 .

Baddeley, A. (2012). Working memory: Theories, models, and controversies. Annual Review of Psychology, 63, I-29. Doi : https://doi.org/I0.I I 46/annrev-psych-I 27 I0-100422.

Baddeley, A. D., Hitch, G. J., \& Allen, R. J. (2009). Working memory and binding in sentence recall. lournal of Memory and Language, 6I(3), 438-456. https:// doi.org//0.1016/j.jml.2009.05.004.

Halsband, U. (2006). Learning in trance: Functional brain imaging studies and neuropsychology. Journal of Physiology, 99(2006). 470-482. https://doi.org/10.1016.

Hastjarjo, T.D. (2004). Taraf kekonkretan kata benda menurut orang Jawa, Sunda, dan Bali. Anima: Indonesian Psychological Journal, 19(3). 234 - 249.

Paivio, A. (20I3). Imagery and verbal processes. Psychology Press.doi.org//0.4324/978I3I57.

Paivio, A., Yuille, J. C., \& Madigan, S. A. (1968). Concreteness, imagery, and meaningfulness values for 925 nouns. lournal of Experimental Psychology, 76(I-2), Doi :http://dx.doi.org// 0.1037/h0025327.

Prakosa, H., Purnamaningsih, E. H., Dewajani, S., \& Hastjarjo, T D. (2008). Penyusunan kumpulan kata benda sebagai sumber tes memori. Buletin Psikologi. I6(2). I I I-I I5.

Solso, R. L., Maclin, O. H., Maclin, M. K. (2008). Psikologi kognitif (terjemahan) (edisi kedelapan). Yogyakarta: Erlangga.

Spreen, O., \& Schulz, R. W. (1966). Parameters of abstraction, meaningfulness, and pronunciability for 329 nouns. Journal of Verbal Learning and Verbal Behavior, 5(5), 459468. Doi:doi.org/10.1016/S0022-537I(66)8006I-0.

Sternberg, J, R. \& Sternberg, K. (20/2). Cognitive psychology, Sixth edition. Belmont. Wadsworth.

Wade, C., \& Tavris, C. (2007). Psikologi umum (terjemahan) jilid I.Yogyakarta: Pustaka Pelajar. 